\title{
Oral mifepristone as adjuvant to prostaglandin E2 (PGE2) gel for preinduction cervical ripening and induction of labour in third trimester
}

\author{
Jitendra D. Mane ${ }^{1}$, Sanjay Singh ${ }^{2 *}$, Anil Kumar Singh ${ }^{1}$
}

\author{
${ }^{1}$ Department of Obstetrics and Gynecology, Military Hospital, Dehradun, Uttarakhand, India \\ ${ }^{2}$ Department of Obstetrics and Gynecology, Armed Forces Medical College, Pune, Maharashtra, India
}

Received: 26 June 2017

Accepted: 25 July 2017

\author{
*Correspondence: \\ Dr. Sanjay Singh, \\ E-mail: drsanjaysingh@gmail.com
}

Copyright: (c) the author(s), publisher and licensee Medip Academy. This is an open-access article distributed under the terms of the Creative Commons Attribution Non-Commercial License, which permits unrestricted non-commercial use, distribution, and reproduction in any medium, provided the original work is properly cited.

\begin{abstract}
Background: Whenever the intrauterine milieu is not conducive for the foetus and continuation of pregnancy may affect adversely to mother and the fetus, termination of the pregnancy is planned. Objective of this work was to study the safety and efficacy of oral mifepristone as adjuvant to PGE2 gel in pre-induction cervical ripening and induction of labour in third trimester.

Methods: 150 patients in third trimester were recruited in this single blind randomized control trial that were planned for delivery with unfavourable cervix. They were randomly allocated into two groups i.e. study group $(n=75)$ who received Tab. Mifepristone $200 \mathrm{mg}$ orally and control group $(\mathrm{n}=75)$ who received placebo orally. At the end of 48 hours (h), change in the Bishop's Score was assessed and those with unfavourable cervix or not in labour, were administered PGE2 gel intracervically every $6 \mathrm{~h}$, for maximum of 3 doses for pre-induction cervical ripening of cervix. Analysis regarding safety and efficacy of the drug was done with regards to maternal and perinatal outcome.

Results: Out of 150 patients, 75 received mifepristone and 75 received placebo. Mean Bishop's Score showed significant improvement after $48 \mathrm{~h}$ in study group (R R 5.135, 95\% CI 4.78 to 5.48) compared to control group (RR $3.43,95 \%$ CI 3.21 to 3.65). Significant number of women went in spontaneous labour in study group (39 v/s 20) (p 0.035 ) in each dose category of PGE2 application. The opportunity to induce labour (with oxytocin) was better in study group in each dose category of intracervical PGE2 gel application. Moreover, lesser number of PGE2 gel was used in study group comparing control group. However, there were no statistical differences in both the groups as far as number of vaginal deliveries and caesearean sections are concerned. Duration of labour in both the groups was same. Neonatal and maternal morbidity was comparable in both the groups.

Conclusions: Mifepristone improves Bishops score when given $48 \mathrm{~h}$ prior to labour induction along with increased number of spontaneous labour and reduced need for PGE2 gel applications, without increasing maternal or neonatal morbidity.
\end{abstract}

Keywords: Mifepristone, PGE2 Gel, Pre-induction cervical ripening, Third trimester pregnancy

\section{INTRODUCTION}

Whenever the intrauterine milieu is not conducive for the foetus and continuation of pregnancy may affect adversely to mother and the fetus, termination of the pregnancy is planned. If there is no contraindication for vaginal delivery then the favourability of cervix helps in predicting success of vaginal delivery. With almost $20 \%$ rate of induction of labour there is a rising trend in the incidence of caesarean sections and repeat caesarean 
deliveries. ${ }^{1}$ Hence there is a need to address this issue. Multiple agents are used for pre-induction cervical ripening and induction of labour. Mifepristone is one of them. Progesterone is responsible for uterine quiescence during pregnancy. Antiprogestins like mifepristone is a antiglucocorticoid and antiprogesterone with higher affinity to progesterone receptors thereby helping in initiation of labour. Mifepristone is characterized by rapid absorption and a long half life of 25-30 h. ${ }^{2}$ Cochrane collaboration published in 2012 is of the opinion that there is insufficient information available from clinical trials to support the use of mifepristone to induce labor. ${ }^{2}$ Hence this study was undertaken to find out the safety and efficacy of mifepristone for pre-induction cervical ripening and labor induction as an adjuvant to PGE2 in the third trimester for women planned for delivery.

\section{METHODS}

This study was conducted in a 500 bedded zonal hospital. It was performed with an aim to find out safety and efficacy of mifepristone when given $48 \mathrm{~h}$ prior to preinduction cervical ripening with PGE2 gel. The study was conducted over a period of one year i.e. from January 2016 to December 2016. Ethical clearance was obtained from institutional ethical committee. It was a single blind randomized controlled clinical trial with 150 women.

\section{Inclusion criteria}

Prolonged pregnancy, preeclampsia, intrauterine growth restriction, Diabetes Mellitus/ GDM, BOH - APLA positive, thrombophilia, past unexplained still birth, singleton gestation, cephalic presentation, IUFD, reassuring NST in live fetus, intact membranes, bishop's score $<6$.

\section{Exclusion criteria}

women with any contraindication to induction and vagina delivery, allergic to prostaglandin, twin gestation, PROM, post caesarean pregnancy, antepartum hemorrhage, abnormal doppler studies, severe oligohydramnios, estimated fetal weight $>4000 \mathrm{gms}$, patient requiring immediate delivery.

150 identical packets were made containing placebo or tab mifepristone. After detailed history, examination, confirmation of diagnosis, investigations and written informed consent, women were allocated into two groups. The participants who received tab mifepristone $200 \mathrm{mg}$ were assigned in Study Group $(\mathrm{n}=75)$ and those who received placebo were included in Control Group $(n=75)$. At the end of $48 \mathrm{~h}$ all women were assessed and Bishop's score was calculated. If the score was $<6$ then PGE2 gel was applied intra-cervically every $6 \mathrm{~h}$ (maximum- three doses) till either cervix became favourable for induction (bishop score $>6$ ) or patient went in labour. Induction or augmentation of labour was done with Oxytocin drip along with artificial rupture of membranes (ARM) only after $6 \mathrm{~h}$ from last dose of PGE2 gel application. Women with Bishop's score <6, unsatisfactory progress of labour or abnormal fetal heart rate pattern suggesting foetal distress, were taken up for caesarean section. The efficacy of mifepristone was assessed on the basis of improvement in Bishop's score, requirement of number of PGE2 gel applications, number of patients going in labour with mifepristone alone or with further use of oxytocin for labour induction and duration of labour. Maternal and perinatal complications were noted if any.

\section{Statistical analysis}

Mean and standard deviations were noted for continuous variables. Chi-square test, unpaired t test and fisher exact test was applied for statistical evaluation. The statistical significance was considered as $<0.05$.

\section{RESULTS}

Characteristics of study subjects with respect to their mean age, mean parity, mean gestational age, and mean Bishop's score were almost similar in both the groups (Table 1).

Table 1: Characteristic of patients.

\begin{tabular}{|llll|}
\hline Characteristic & $\begin{array}{l}\text { Study } \\
\text { group } \\
(\mathbf{n}=75)\end{array}$ & $\begin{array}{l}\text { Control } \\
\text { group } \\
(\mathrm{n}=75)\end{array}$ & $\begin{array}{l}\text { p } \\
\text { value }\end{array}$ \\
\hline $\begin{array}{l}\text { Mean Age } \\
\text { (mean } \pm \text { SD) }\end{array}$ & $25.21 \pm 3.82$ & $25.54 \pm 4.25$ & $0.626^{\#}$ \\
\hline $\begin{array}{l}\text { Mean Parity } \\
\text { (mean } \pm \text { SD) }\end{array}$ & $1.56 \pm 0.66$ & $1.44 \pm 0.60$ & $0.244^{\#}$ \\
\hline $\begin{array}{l}\text { Mean gestational } \\
\text { age (mean } \pm S D)\end{array}$ & $39.53 \pm 1.30$ & $39.38 \pm 1.52$ & $0.519^{\#}$ \\
\hline $\begin{array}{l}\text { Mean Bishop's } \\
\text { score (mean } \pm S D)\end{array}$ & $2.86 \pm 1.05$ & $2.77 \pm 0.92$ & $0.562^{\#}$ \\
\hline
\end{tabular}

Significant improvement in mean Bishop's score was noted following use of mifepristone alone after $48 \mathrm{~h}$ in study group (RR 5.135, $95 \%$ CI 4.78 to 5.48) compared to control group (RR 3.43, $95 \%$ CI 3.21 to 3.65). Four $(5.30 \%)$ women in the study group and two $(2.60 \%)$ women in the control group went in spontaneous labour within $24 \mathrm{~h}$ (Table 2).

Table 2: Effects of mifepristone alone.

\begin{tabular}{|llll|}
\hline Characteristic & $\begin{array}{l}\text { Study } \\
\text { group } \\
(\mathrm{n}=75)\end{array}$ & $\begin{array}{l}\text { Control } \\
\text { group } \\
(\mathrm{n}=75)\end{array}$ & $\begin{array}{l}\text { p } \\
\text { value }\end{array}$ \\
\hline $\begin{array}{l}\text { Spontaneous } \\
\text { labour }\end{array}$ & $4(5.30 \%)$ & $2(2.60 \%)$ & \\
\hline $\begin{array}{l}\text { Mean Bishop's } \\
\text { score }\end{array}$ & $4.70 \pm 1.54$ & $4.08 \pm 1.058$ & $0.0059^{\#}$ \\
\hline $\begin{array}{l}\text { at the end of } \\
\text { 48h }\end{array}$ & $\begin{array}{l}\text { RR-5.135, } \\
95 \% \text { CI }\end{array}$ & $\begin{array}{l}\text { RR- 3.43, } \\
95 \% \text { CI }\end{array}$ & \\
\hline \begin{tabular}{l} 
(mean \pm SD) \\
\hline
\end{tabular} & 4.78 to 5.48 & 3.21 to 3.65 & \\
\hline
\end{tabular}


Following instillation of 1st dose of PGE2 gel six (8.45 $\%$ ) women went in spontaneous labour in the study group $(\mathrm{n}=71)$ and only one $(2.73 \%)$ in the control group $(\mathrm{n}=$ 73 ). Fifteen $(21.12 \%)$ and eight $(9.58 \%)$ women could be induced from study and control group respectively as the Bishop's score was more then 6 after $6 \mathrm{~h}$. Thus, number of women who went in spontaneous labour or who could be induced because of favourable cervix following first
PGE2 gel was significantly more in study group (p 0.011).

Following application of 2nd dose of PGE2 gel sixteen $(32 \%)$ women went in spontaneous labour and four (12.5 $\%)$ women could be induced in study group $(\mathrm{n}=50)$ which was significantly more than the control group $(\mathrm{n}=$ 64) (p-0.0001).

Table 3: Effects of PGE2 gel following mifepristone.

\begin{tabular}{|c|c|c|c|c|c|c|}
\hline \multirow[t]{2}{*}{ Characteristic } & \multirow[t]{2}{*}{ Subgroup } & \multicolumn{2}{|c|}{ Study group } & \multicolumn{2}{|c|}{ Control group } & \multirow[t]{2}{*}{ p value } \\
\hline & & $\mathbf{N}$ & $\%$ & $\mathbf{N}$ & $\%$ & \\
\hline \multirow[t]{5}{*}{$1^{\text {st }}$ PGE2 gel } & & 71 & 94.66 & 73 & 97.33 & \\
\hline & A. Spontaneous labour & 21 & 29.57 & 9 & 12.32 & $0.011^{\# \#}$ \\
\hline & + Bishops score $>6$ & & & & & \\
\hline & a. Spontaneous labour & 6 & 8.45 & 1 & 2.73 & $0.06^{\$}$ \\
\hline & b. Bishop's score $>6$ & 15 & 21.12 & 8 & 9.58 & $0.09^{\# \#}$ \\
\hline \multirow[t]{5}{*}{$2^{\text {nd }}$ PGE2 gel } & & 50 & 66.66 & 64 & 85.33 & \\
\hline & B. Spontaneous labour & 26 & 52 & 13 & 20.31 & $0.0001^{\# \#}$ \\
\hline & + Bishops score $>6$ & & & & & \\
\hline & a. Spontaneous labour & 16 & 32 & 4 & 12.5 & $0.0001^{\# \#}$ \\
\hline & b. Bishop's score $>6$ & 10 & 20 & 9 & 7.85 & $0.39^{\# \#}$ \\
\hline \multirow[t]{6}{*}{$3^{\text {rd }}$ PGE2 gel } & & 24 & 32 & 51 & 68 & \\
\hline & C. Spontaneous labour & 22 & 91.66 & 47 & 92.15 & $0.99^{\$}$ \\
\hline & + Bishops score $>6$ & & & & & \\
\hline & a. Spontaneous labour & 13 & 54.16 & 13 & 27.45 & $0.015^{\# \#}$ \\
\hline & b. Bishop's score >6 & 9 & 37.5 & 34 & 64.70 & $0.17^{\# \#}$ \\
\hline & c. Bishop's score $<6$ & 2 & 8.33 & 4 & 7.84 & \\
\hline
\end{tabular}

$3^{\text {rd }}$ dose of PGE2 gel was applied in remaining women with unfavourable cervix i.e study group $(n=24)$ and control group $(\mathrm{n}=51)$. Thirteen women $(54.16 \%)$ from study group and thirteen $(27.45 \%)$ women from control group went in spontaneous labour. Nine $(37.5 \%)$ in the study group with Bishop's score more than six were induced comparing thirty-four $(64.70 \%)$ from control group. Thus, requirement of third dose of PGE2 gel was significantly less in the study group. Two women from study group and four from control group had unfavourable cervix after three applications of PGE2 gel (Table 3).

As far as overall efficacy is concerned more women in study group (thirty nine v/s twenty) ( $\mathrm{p}-0.035)$ went in spontaneous labour. Also, significant number of women could be induced from study group compared to control group in view of more cases of favourable cervix.

Total number of PGE2 gel used was less in study group than the control group. However, there was no statistical difference in both the groups as far as number of vaginal deliveries and caesarean sections was concerned. Duration of labour in both the groups was comparable (Table 4).
Table 4: Overall efficacy of mifepristone with PGE2 gel.

\begin{tabular}{|llll|} 
Characteristic & $\begin{array}{l}\text { Study } \\
\text { group } \\
(\mathbf{n = 7 5 )}\end{array}$ & $\begin{array}{l}\text { Control } \\
\text { group } \\
(\mathbf{n = 7 5 )}\end{array}$ & $\begin{array}{l}\text { p } \\
\text { value }\end{array}$ \\
\hline $\begin{array}{l}\text { Spontaneous } \\
\text { labour }\end{array}$ & $39(52 \%)$ & $\begin{array}{l}20 \\
(26.66 \%)\end{array}$ & $0.035^{\# \#}$ \\
\hline $\begin{array}{l}\text { Bishops score > } 6 \\
\text { (labour Induced) }\end{array}$ & 34 & 51 & $0.002^{\# \#}$ \\
\hline Total PGE2 utilized & 145 & 188 & \\
\hline Vaginal delivery & 68 & 66 & $0.597^{\# \#}$ \\
\hline Caesarean section & $7(90.66 \%)$ & $(88 \%)$ & \\
\hline a. Failed induction & 2 & 4 & \\
\hline b. Foetal distress & 2 & 1 & \\
\hline $\begin{array}{l}\text { c. Non-progress of } \\
\text { labour }\end{array}$ & 3 & 3 & \\
\hline Duration of labour & $6.8 \pm 1.59$ & $6.93 \pm 1.49$ & $0.628^{\#}$ \\
\hline
\end{tabular}

NICU admissions in study group were four (5.3\%) and in control group three $(4 \%)$. Meconium stained liquor found in study and control group as shown in table 4 was not significant -sixteen $(21.33 \%)$ vs twelve (16\%). 
Adverse maternal effects encountered were comparable in both the groups (Table 5).

Table 5: Neonatal effect.

\begin{tabular}{|llll|}
\hline Characteristic & $\begin{array}{l}\text { Study } \\
\text { group } \\
(\mathbf{n = 7 5 )}\end{array}$ & $\begin{array}{l}\text { Control } \\
\text { group } \\
(\mathbf{n = 7 5})\end{array}$ & p value \\
\hline $\begin{array}{l}\text { Meuconium } \\
\text { stained liquor }\end{array}$ & $6(8 \%)$ & $8(10.6 \%)$ & $0.575^{\$}$ \\
\hline $\begin{array}{l}\text { NICU } \\
\text { admission }\end{array}$ & $3(2.25 \%)$ & $2(1.5 \%)$ & $0.99^{\$}$ \\
\hline $\begin{array}{l}\text { \#unpaired 't' } \\
\text { test }\end{array}$ & $\begin{array}{l}\text { \#\#Chi } \\
\text { square test }\end{array}$ & \$Fisher's exact test \\
\hline
\end{tabular}

\section{DISCUSSION}

Different modalities are available for induction of labour with an aim of vaginal delivery. In present study mifepristone $200 \mathrm{mg}$ was used as adjuvant to PGE2 gel for cervical ripening and labour induction. Single dose of mifepristone $200 \mathrm{mg}$ was found to be effective for cervical ripening at $72 \mathrm{~h}$ (RR2.13, 95\% CI 1.15-3.97) as reported by Hapangama and Neilson. ${ }^{2}$ The similar finding has also been reported by Yelakar et al and Atawale et al. ${ }^{3,4}$ However, Wing et al did not found significant cervical changes with the use of mifepristone. ${ }^{5}$ This study showed significant changes in Bishops score after $48 \mathrm{~h}$. Number of PGE2 gel required to be used in the study group was less than the control group (145 vs 188). Present study corroborates the finding of Hapangama and Neilson wherein they have recorded high incidences of women going in spontaneous labour and having favourable cervix after $48 \mathrm{~h}$ (RR 2.9, 95\% CI 1.70-3.42). ${ }^{2}$ Similar endorsement has also been made by Frydmann et al and Yelakar et al. ${ }^{3,6}$ In present study in each group of PGE2 gel application $\left(1^{\text {st }}, 2^{\text {nd }}\right.$ or $\left.3^{\text {rd }}\right)$ more number of women went in spontaneous labour in the study group without requiring oxytocin for induction. The incidence of cesarean section was not significantly reduced in our study though Hapangama and Neilson and Fathima et al have reported reduced caesarean rate. ${ }^{2,7}$ NICU admissions and Meconium stained liquor was almost same in both groups contrary to Hapangama and Neilson's study which showed increase abnormal foetal heart patterns in mifepristone group. ${ }^{2}$

\section{CONCLUSION}

With increasing incidence of induction of labour for various indications there is a need of finding out better treatment modalities for cervical priming and induction of labour to achieve successful vaginal deliverers with minimal maternal and neonatal morbidities. Mifepristone used as adjunct $48 \mathrm{~h}$ prior to PGE2 gel is an effective intervention for better cervical ripening, inducing labour and reducing need for PGE2 gel applications, without increasing maternal or neonatal morbidity. Further studies are recommended to establish the protocol.

Funding: No funding sources

Conflict of interest: None declared

Ethical approval: The study was approved by the Institutional Ethics Committee

\section{REFERENCES}

1. Mealing NM, Roberts CL, Ford JB, Simpson JM, Morris JM. Trends in induction of labour, 19982007: a population-based study. Aust N Z J Obstet Gynecol. 2009;49:599-605.

2. Hapangama D, Neilson JP. Mifepristone for induction of labour. Cochrane Database Syst Rev 2009;(3): CD002865.

3. Yelikar K, Deshpande S, Deshpande R, Lone D. Safety and efficacy of oral mifepristone in preinduction cervical ripening and induction of labour in prolonged pregnancy. J Obstet Gynecol India. 2015;65(4):221-5.

4. Athawale R, Acharya N, Samal S, Hariharan C. Effect of mifepristone in cervical ripening for induction of labour. Int $\mathbf{J}$ Reprod Contracept Obstet Gynecol. 2013;2(1):35-8.

5. Wing DA, Fassett Michael J, Mishell Daniel R. Mifepristone for preinduction cervical ripening beyond 41 weeks' gestation: a randomized controlled trial. Obstet Gynecol. 2000;96:543-8.

6. Frydman R, Lelaidier C, Baton-Saint-Mleux C, Fernandez H, Vial M, Bourget P. Labour induction in women at term with mifepristone (RU 486): a doubleblind randomized, placebo-controlled study. Obstet Gynecol.1992;80:972-5.

7. Fathima S, Nayak SR, Rao B. Mifepristone in induction of labour at term. Int J Pharm Biomed Res. 2013;4(3):164-6.

Cite this article as: Mane JD, Singh S, Singh AK. Oral mifepristone as adjuvant to prostaglandin E2 (PGE2) gel for preinduction cervical ripening and induction of labour in third trimester. Int J Reprod Contracept Obstet Gynecol 2017;6:3952-5. 